\title{
Operational study of roundabouts and signal-controlled intersections in Kaunas City
}

\author{
Vytautas Dumbliauskas, Vytautas Grigonis, Andrius Barauskas \\ Department of Urban Engineering, Vilnius Gediminas Technical University, Sauletekio ave. 11, 10223 Vilnius, Lithuania
}

\begin{abstract}
Researchers and practitioners often discuss which types of junctions are more efficient in urban territories. Consequently, a proper decision is important in order to minimize the costs of infrastructure for users and government. The aim of the study is to assess and compare operation of roundabouts and signal-controlled intersections under various traffic conditions. The study is based on traffic measurements and data about road accidents. Efficiency of operation is calculated and compared, proposals are given.
\end{abstract}

Keywords: Traffic safety; roundabouts; signal-controlled intersections; Kaunas City.

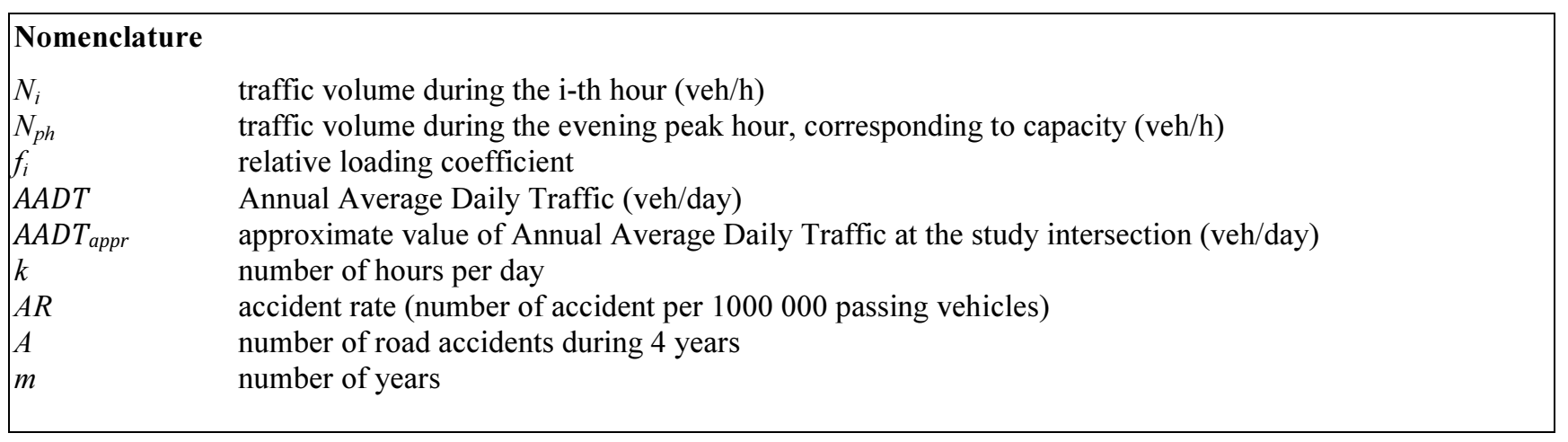

\section{Introduction}

Operation of roundabouts could be assessed from several perspectives: traffic safety, time expenditure, vehicle operating costs and fuel consumption. This article aims to compare operation of roundabouts and signal-controlled intersections in urban conditions taking into consideration a traffic safety factor. The article is based on a map of fatal and injury accidents in Kaunas City created by the authors of the article and on measurements of traffic volume. Traffic volume measurements were performed during the evening peak when traffic jams are being formed and traffic volume corresponds to the capacity of intersections. During this study the level of safety at roundabouts and signal-controlled intersections was assessed by calculating accident rate. The values of accident rates were compared depending on a changing capacity of intersections. The article gives final conclusions.

\section{General}

Based on data of Lithuanian Department of Statistics, in the year 2012 in Lithuania 3492 fatal and injury accidents took place where 302 people were killed and 3952 were injured [1]. Statistically, in 2012 in Lithuania a fatal or injury accident occurred every two and a half hours. In 2012, 101 people were killed on the roads of Lithuania per one million inhabitants. And though over the last years Lithuania has made a large progress in the field of traffic safety, on the European scale it still remains the last between 28 EU member-states [2].

Corresponding author: Vytautas Dumbliauskas. E-mail address: v.dumbliauskas@gmail.com

http://dx.doi.org/10.3846/enviro.2014.116

(C) 2014 The Authors. Published by VGTU Press. This is an open-access article distributed under the terms of the Creative Commons Attribution License, which permits unrestricted use, distribution, and reproduction in any medium, provided the original author and source are credited. 
The largest part of road accidents (in Lithuania - about 65\%) occur in the built-up territories, luckily, they result in fewer people deaths than in rural territories [3]. It is obvious, that a higher amount and a lower severity of accidents are conditioned by more intensive traffic flows and lower speeds.

From the safety point of view, urban intersections is especially important element since a meta-analysis of different studies made by R. Elvik [4] showed that namely the urban intersections represent almost 40 percent of all fatal and injury accidents.

Two types of accident rates are described in literature [5] and widely used in practice: population-based and exposurebased. The mentioned accident rates represent a ratio between the number of accidents and the distance travelled or the time spent for the journey. Since for the intersections neither of them makes sense, the event-based accident rate was used [5]. In Lithuania such index is also calculated to assess the level of safety of road. It indicates the number of accidents on a certain road section per one million of passing vehicles [6].

\section{The study territory}

The study territory is situated in the northern part of the city, on both sides of Savanoriu Avenue - a continuation of the main road A6. The total study area amounts to $8 \mathrm{~km}^{2}$ and makes 5,1 percent of the total area of Kaunas City. The territory is crossed and joined up by high-category streets.

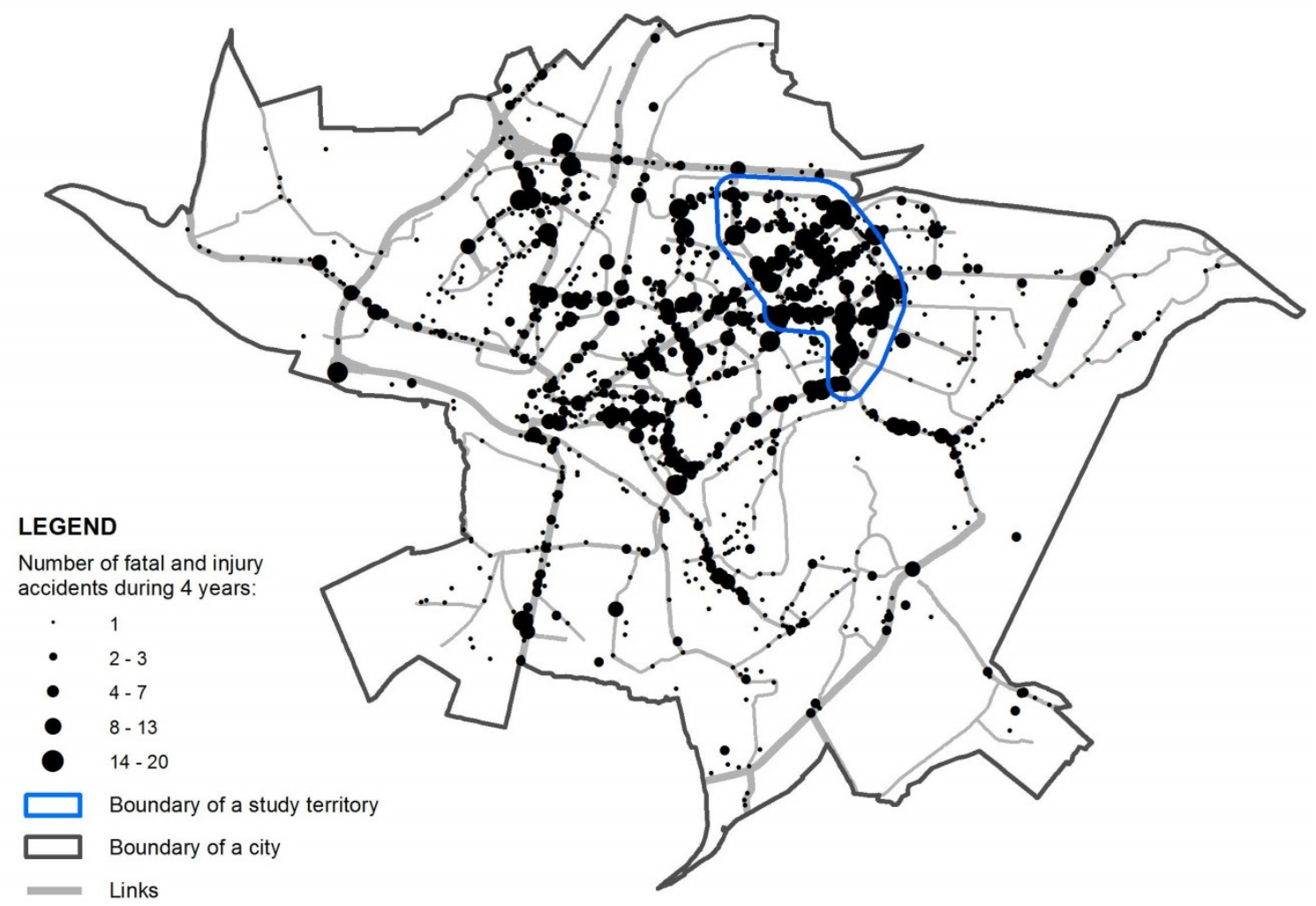

Fig. 1. The study territory in the context of Kaunas City

High-category streets, which ensure permanent connections between functional zones of the city, have an especially high traffic volume, in some places amounting to $1700 \mathrm{veh} / \mathrm{h}$ in one direction. Seeking to ensure their capacity, complex and complicated intersections have been designed. And though the density of street network in the study territory $\left(5.38 \mathrm{~km} / \mathrm{km}^{2}\right)$ is lower than the average in the whole city $\left(5.85 \mathrm{~km} / \mathrm{km}^{2}\right)$, the largest part of links are of category B and C, and only a small part - of category D. All this creates preconditions for a higher amount of accidents. It's hardly surprising that in the period 2007-2010 the study territory accounted for 639 fatal and injury accidents, and this makes 23.5 percent of the total number of accidents having occurred in the Kaunas City during the mentioned period.

One of the reasons for a large number of accidents is that the territory is very intensively settled. A residential density in this location amounts to 110 residents/ha, whereas, the average residential density of the city is 21.5 residents/ha.

\section{Traffic measurements at the intersections of the study territory}

In the study territory roundabouts and signal-controlled intersections were studied where the main (of category B) and subsidiary (of category C) streets cross each other. It should be emphasized that only four-leg intersections were taken into consideration. 
The object of the study is 15 intersections situated within the study territory and meeting the above criteria. All of them are at-grade intersections. It should be noted that 5 intersections are of roundabout type and controlled by road signs and ten intersections are controlled by traffic lights.

For the accident analysis the Annual Average Daily Traffic (AADT) of each intersection is necessary. In order to calculate AADT, at all intersections the on-site measurements of traffic flows were carried out. A flow of vehicles was measured in November 2011. Measurements were taken during the evening peak $(16-18 \mathrm{~h})$.

In four-leg signal-controlled intersections the flow of entering vehicles varied from $2803 \mathrm{veh} / \mathrm{h}$ to $4956 \mathrm{veh} / \mathrm{h}$. Whereas, in four-leg roundabouts the traffic flow varied from $2826 \mathrm{veh} / \mathrm{h}$ to $4000 \mathrm{veh} / \mathrm{h}$. Since traffic flows were measured during the peak hours, formation of traffic jams and lines was observed at all the intersections. This means that the intersections operated under the conditions of saturated traffic flow. It could be assumed that the measured traffic volumes are identical to the capacity of those intersections.

AADT could be calculated based on a short-term measurement data. In literature [7] a multi-stage methodology is given for calculating AADT. This methodology uses parameters obtained from the analysis of traffic volume of all the roads of national significance of the country, therefore, it would be a wrong decision to use this methodology implicitly. When calculating AADT of the study intersections and seeking for the most accurate results the analysis was made of the average annual hourly traffic on the roads of national significance situated in the approaches of Kaunas City. This data, with the help of automatic counters-classifiers, was recorded and analyzed by the Public Enterprise Road and Transport Research Institute (formerly - State Enterprise Transport and Road Research Institute). Five measuring posts were analyzed on the main roads (two on the road A1, two on the road A5 and one on the road A6) and two measuring posts on the national roads (No. 130 and No. 139). First of all, based on data collected by the Road and Transport Research Institute, the relative hourly loading coefficients were determined for each of suburban posts. Those coefficients were calculated as follows:

$$
f_{i}=\frac{N_{i}}{N_{p h}}
$$

Finally, the resultant relative loading coefficients were calculated representing relative loadings of all the mentioned roads. Coefficients are given in the figure below.

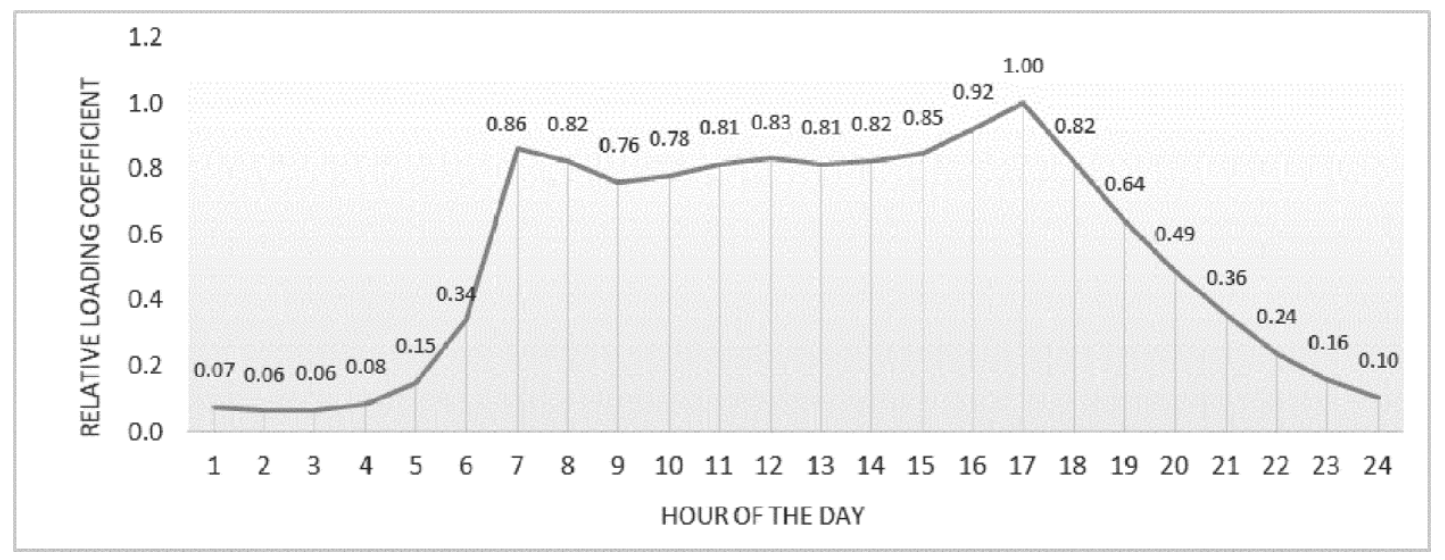

Fig. 2. Relative loading coefficients for suburban roads

Thus, according to Figure 2 the Annual Average Daily Traffic at the study intersections can be approximately calculated according to the following formula:

$$
A A D T_{\text {appr }}=\sum_{i=1}^{k} f_{i} \times N_{p h}
$$

Results are presented in Table 1.

\section{Road accidents and accident rates}

At national level, data on fatal and injury accidents is collected in GIS databases, further it is analyzed and generalized. The Road and Transport Research Institute carries out systematic investigations of safety level on main and national roads and creates the maps of black spots. City streets fall within the competence of municipalities and due to the lack of financing no investigations are conducted in the field of their safety or conducted only in exceptional cases.

In the framework of this study the authors analyzed data about fatal and injury accidents in Kaunas City in the period 2007-2010. Data was provided by the Traffic Police Board of Kaunas County Police Headquarters. Each fatal or injury accident is described by its location, type and the number of people killed or injured. With the help of GIS the authors distributed those accidents in the whole territory of Kaunas City (Fig. 1). For a more detail analysis of accidents within the 
limits of selected territory it was necessary to determine the number of road accidents per each of 15 intersections. For this purpose, accidents that occurred within the intersection and close to it were analysed. Each intersection was attributed with the accidents that occurred in its centre and at a $100 \mathrm{~m}$ distance to its approaches. In the authors' opinion, the distance of $100 \mathrm{~m}$ is quite reasonable since under a high traffic volume the impact of intersection on traffic conditions is felt even at a larger distance than $100 \mathrm{~m}$. A short description of each road accident was analyzed in order to prevent intersections from attributing events not related to them, e.g. accidents recorded in a parking lot beside the intersection. Further, data about fatal and injury accidents were used to calculate the accident rate of intersections (Table 1).

\section{The tendencies of accident rate at the intersections of different capacity}

In order to determine the safety level of all intersections it is necessary to calculate accident rate (AR). Accident rate indicates the number of accidents per million vehicles passing through the road section. AR is commonly used for assessing safety level on the roads of national significance, however, in this study the AR was adjusted by analogy for the assessment of safety level of intersections. Description of the accident rate and its calculation formula are given in the Methodology for Identifying High-Accident Sections on the Roads of National Significance [6]:

$$
A R=\frac{A \cdot 10^{6}}{365 \cdot A A D T \cdot m}
$$

Calculation results are given in Table 1.

Table 1. Summary table of measurements and calculations (Intersections can be identified with a help of Appendix A)

\begin{tabular}{|c|c|c|c|c|c|c|}
\hline No. & Name of an intersection & Type of control & $\begin{array}{l}\mathbf{N}_{\text {ph }} \\
\text { veh/h }\end{array}$ & $\begin{array}{l}\text { AADT }_{a p p r} \\
\text { veh/day }\end{array}$ & $\begin{array}{l}\text { Number of accidents } \\
\text { during } 4 \text { years }\end{array}$ & $\mathbf{A R}$ \\
\hline 1 & Kovo 11-osios Str. - Chemijos Av. - Dujotiekio Str. & Signal-controlled & 2803 & 36019 & 23 & 0,437 \\
\hline 2 & P. Lukšio Str. - Savanorių Av. - Kovo 11-osios Str. & Signal-controlled & 3104 & 39886 & 22 & 0,378 \\
\hline 3 & Parizanu Str. - Kovo 11-osios Str. & Signal-controlled & 2479 & 31855 & 14 & 0,301 \\
\hline 4 & Birželio 23-iosios Str. - Partizanų Str. & Signal-controlled & 2908 & 37368 & 13 & 0,238 \\
\hline 5 & $\begin{array}{l}\text { Savanorių Av. - Žukausko Str. - Birželio 23-iosios } \\
\text { Str. }\end{array}$ & Signal-controlled & 3870 & 49710 & 17 & 0,234 \\
\hline 6 & Pramonės Str. - Savanorių Av. - Šiaurès Av. & Signal-controlled & 4956 & 63685 & 19 & 0,204 \\
\hline 7 & S. Žukausko Str. - P. Lukšio Str. & Signal-controlled & 3265 & 41955 & 11 & 0,180 \\
\hline 8 & Draugystès Av. - Pramonės Av. & Signal-controlled & 4283 & 55037 & 13 & 0,162 \\
\hline 9 & Pramonės Av. - Partizanų Str. & Signal-controlled & 3507 & 45065 & 7 & 0,106 \\
\hline 10 & Birželio 23-iosios Str. - Baranausko Str. - Taikos Av. & Signal-controlled & 4680 & 60138 & 9 & 0,103 \\
\hline 11 & Taikos Av. - Pramonès Av. & Roundabout & 4000 & 51400 & 18 & 0,240 \\
\hline 12 & Kovo 11-osios Str. - V. Krèvės Av. & Roundabout & 2896 & 37214 & 10 & 0,184 \\
\hline 13 & V. Krèvės Av. - Pramonès Av. & Roundabout & 3898 & 50089 & 13 & 0,178 \\
\hline 14 & Šiaurės Av. - S. Žukausko Str. - Ašigalio Str. & Roundabout & 3158 & 40580 & 8 & 0,135 \\
\hline 15 & Chemijos Av. - Pramonès Av. & Roundabout & 2826 & 36314 & 2 & 0,038 \\
\hline
\end{tabular}

The tendencies of the change in accident rate would be more apparent if located on Y-axis, where intersection capacity is located on X-axis (Fig. 3).

It is obvious that at signal-controlled intersections there is a weak inversely proportional relationship between traffic capacity and accident risk. It could be stated that with the increasing capacity (also traffic volume) the number of accidents decreases. However, for roundabouts this relationship is opposite - with the increasing capacity (also traffic volume) the number of accidents increases. A conclusion could be drawn that at intersections which accommodate high traffic flows it is more favourable to control traffic by using traffic-lights, whereas, roundabouts are more suitable for lower flows. Based on data of investigations, the "breaking point", describing a capacity of traffic flow and if exceeded makes the signal-controlled intersections safer than roundabouts, is about $3890 \mathrm{veh} / \mathrm{h}$. 


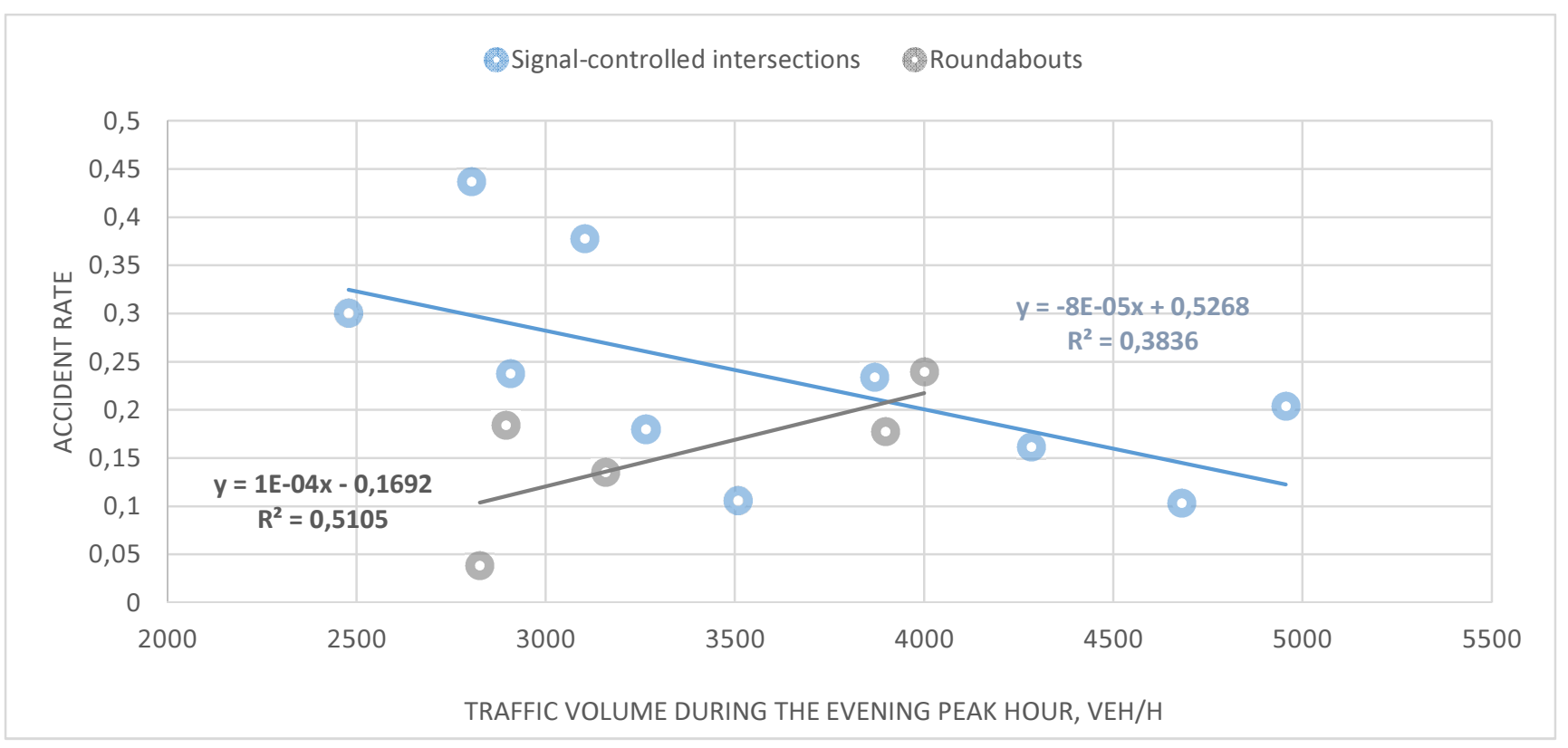

Fig. 3. The tendencies of accident rate at the study intersections

The increasing number of accidents at roundabouts can be explained by the growing number of conflict points with the increasing capacity of roundabouts. This happens because in order to accommodate high traffic flows the complex largediameter roundabouts are designed.

As stated by assoc. prof. A. Klibavičius, the number of conflict points which in literature is usually given without considering the change of lanes by traffic flows, depends on several factors [9]:

- traffic organization at the intersection;

- internal diameter of the roundabout;

- the entering traffic flows;

- distribution of traffic flows on each entrance between separate exits;

- number of traffic lanes at the roundabout;

- number of traffic lanes on the entrances to the roundabout.

Besides, under high traffic volume the increased time losses force the drivers to break traffic rules and to behave undisciplined.

Whereas, the decreasing number of accidents at the signal-controlled intersections with the increasing traffic volume can be related to the drivers' discipline, since at this type of intersections the drivers have less possibilities to break traffic rules. Vehicles are allowed to pass the intersection in groups, thus, it is easier for each driver to orient in traffic and to safely cross the intersection.

\section{Conclusions}

Based on data of on-site traffic measurements and fatal and injury accidents, for each four-leg intersection within the study territory the accident rate was calculated. Two models of the relationship between accident rate and traffic volume were developed. The first model describes roundabouts. Its expression is: $y=(1 E-04) x-0.1692$, coefficient of determination $R^{2}=0.5105$, number of observations -5 . The second model describes signal-controlled intersections. Its expression is: $y=-(8 E-05) x-0.5268$, coefficient of determination $-R^{2}=0.3836$, number of observations -10 .

At the studied signal-controlled intersections of Kaunas City there is a weak inversely proportional relationship between traffic capacity and accident risk. This means that with the increasing capacity (also traffic volume) the number of accidents decreases. However, for the studied roundabouts this relationship is opposite - with the increasing capacity the number of accidents increases. The "breaking point", describing a capacity of traffic flow and if exceeded makes the signal-controlled intersections safer than roundabouts, is about $3890 \mathrm{veh} / \mathrm{h}$.

It should be emphasized that the study intersections were designed and built according to the soviet normative documents. The current intersection design standards are more advanced in the field of traffic safety. The tendencies in the number of accidents at urban intersections (especially roundabouts) which were designed according to the modern standards still remain unclear, thus, it is planned to develop their research and to further analyse data in a complex way.

Comparison of intersections according to only one index, i.e. traffic safety, is not fully objective and does not meet the principles of sustainable development. A complex evaluation is necessary comprising another not less important indices, such as drivers' time losses, vehicle fuel consumption and other operating costs. In further research it is planned to assess another mentioned criteria. 


\section{References}

[1] The Department of Statistics (Statistics Lithuania). Official statistics portal. [Online] 2013. [Cited: 12 December 2013]. Available from Internet: http://www.stat.gov.lt/en/home.

[2] European Commission. European Commission, Mobility and Transport, Road Safety. [Online] 2013. [Cited: 18 December 2013]. Available from Internet: http://ec.europa.eu/transport/road safety/specialist/statistics/index en.htm.

[3] Lithuanian Road Administration. 2013. Statistics of Fatal and Injury Road Accidents in Lithuania. [CD]. Vilnius.

[4] Elvik, R.; Høye, A.; Vaa, T.; Sørensen, M. 2009. The Handbook of Road Safety Measures. Oslo: Emerald Group Publishing Limited.

[5] Roess, R. P.; Prassas, E. S.; McShane, W. R. 2012. Traffic Engineering. United States: Prentice Hall.

[6] Avaringu ruožu nustatymo valstybinés reikšmès keliuose metodika [The Methodology for Identifying High-Accident Sections on the Roads of National Significance]. Vilnius. 2011.

[7] Čygas, D.; Žilionienè, D.; Vitkienė, J. 2009. Automobiliu keliu projektavimas [Road Design]. Vilnius: Technika. http://dx.doi.org/10.3846/1085-S

[8] PE "Road and Transport Research Institute". 2010. Report of AADT.

[9] Klibavičius, A. 2008. Simulation of Capacity of Roundabouts Applying Principles of Sustainable Urban Development, in $7^{\text {th }}$ International Conference "Environmental Engineering", Vilnius.

\section{Appendix A. A scheme of study intersections}

LEGEND

Boundary of study territory

Link of category B1 (Major Arterial)

L Link of category B2 (Minor Arterial)

Link of category C1 (Major Collector)

Link of category C2 (Minor Collector)

Link of category D1 (Local Street)

Detailed characteristics of each study intersection can be found in Table 1. 